\title{
Alle trenger støtte når mamma eller pappa er syk
}

Alvorlig sykdom og et usikkert sykdomsforløp kan redusere foreldrenes omsorgskapasitet for barn. For å imøtekomme både foreldres og barns behov bør hele familien støttes.

\section{Forfatter}

\section{May Aasebø Hauken}

Forsker

Senter for krisepsykologi, Universitetet i Bergen

\section{Nøkkelord}
Familie
Kreft
Psykososiale tiltak
Sosialt nettverk
Barn

Sykepleien 2017 105(64175)(e-64175)

DOI: https://doi.org/10.4220/Sykepleiens.2017.64175

\section{HOVEDBUDSKAP}

Det trengs både emosjonell, sosial, økonomisk og praktisk nettverksstøtte til kriserammete familier. Familien er en enhet og det totale nettverket må kartlegges. Sykepleiere er viktige bidragsytere gjennom å formidle forståelse og kunnskap om betydningen av god sosial nettverksstøtte. Fokuset for denne artikkelen er prinsipper for sosial nettverksstøtte når mor eller far er syk, eksemplifisert med kreft. Artikkelen bygger spesielt på forskning fra Senter for Krisepsykologi. 
Sosial støtte er svært viktig for alle menneskers

livskvalitet og helse, og spesielt for familier i krise (1).

Forskning viser imidlertid at foreldre i en

krisesituasjon etterlyser mer støtte og langvarig hjelp, mens nettverket ofte føler seg utrygge og usikre på hvordan de kan være til hjelp (2-4). Tidsklemma med omsorg for barn, jobb og daglige oppgaver, innebærer en betydelig tilleggsbelastning for hele familien ved alvorlig sykdom hos en av foreldrene, som for eksempel ved kreft (5).

Mange familier lever med alvorlig sykdom over mange år, ofte preget av et varierende og usikkert sykdomsforløp (6). Disse familiene kan befinne seg i en langvarig krisesituasjon forstått som «en situasjon med en avgjørende fare for liv og helse i et sykdomsforløp, eller som forstyrret psykisk likevekt ved store påkjenninger. Slik kan en krise betegne en så alvorlig påkjenning at en families eksistens trues» (7). Belastningene, reaksjonene og utfordringene vil imidlertid variere for enkeltindivider og fra familie til familie.

\section{Rolleendring og omsorgskapasitet}

Sykdom og behandling kan medføre store konsekvenser på alle områder i livet. For pasienten kan behandlingen medføre fysiske bivirkninger og senskader der fatigue er hyppig (8), samt psykiske reaksjoner som angst, depresjon og traumatiske stressreaksjoner (9). Syke foreldre rapporterer om rolletap og redusert kapasitet knyttet til jobb, praktiske oppgaver hjemme, omsorg for barna og sosialt liv (4). Tilsvarende opplever den friske forelderen økt rollebelastning knyttet til omsorg for barna, syk partner og dagliglivets oppgaver $(2,4,10)$. Disse rapporterer om alvorlige konsekvenser for samliv, familieliv og kommunikasjon (11), stressreaksjoner, angst og depresjon $(10,12)$. Til sammen medfører dette en redusert livskvalitet og omsorgskapasitet for foreldrene (2). 


\section{三 «Mange familier opplever at nettverket trekker seg bort.»}

Foreldrene er primært opptatt av å beskytte og ivareta barna, og opprettholde hverdagslivet (13). De etterlyser mer hjelp fra sine sosiale nettverk for å få hverdagen til å gå rundt i en vanskelig tid $(4,14)$. Mange familier opplever imidlertid at nettverket trekker seg bort, eller at hjelpen ikke er relevant, som for eksempel «gode råd». Mange foreldre synes dessuten det er vanskelig å be om hjelp. En far sa: «Selv om de sier: 'Bare ring hvis det er noe jeg kan gjøre', så gjør jeg jo ikke det».

\section{Å være barn}

Barn som lever med en alvorlig syk forelder, påvirkes ut fra alder, erfaring og modenhet $(4,5)$, samt sykdommens alvorlighetsgrad, foreldrenes mestring, omsorgskapasitet og hvordan hverdagslivet fungerer $(4,5,15)$. Det er en klar sammenheng mellom foreldrenes og barnas psykososiale vanskeligheter. Redusert foreldremestring påvirker barnas atferd, emosjonelle og fysiske funksjon og skoleprestasjoner $(16,17)$.

De minste barna påvirkes mest av endringer $\mathrm{i}$ dagliglivets rutiner og foreldrenes atferd, som for eksempel sykehusinnleggelser og uttrykk for tristhet, tretthet eller utålmodighet. Eldre barn opplever i tillegg empati for foreldrene, bekymringer for utfallet og påvirkning på egen framtid $(4,18)$. Barn som lever med alvorlig sykdom i familien over tid, sliter ofte med fysiske, psykiske, sosiale og eksistensielle problemer, og har en økt risiko for å utvikle angst, depresjon, traume- og (vente-) sorgreaksjoner og redusert livskvalitet $(11,18,19)$.

\section{Interaksjonen i familien}


Alvorlig sykdom hos foreldre påvirker interaksjonen mellom familiemedlemmene, der det er en klar sammenheng mellom redusert familiefungering og redusert psykososial funksjon hos barn $(11,17)$. Barn kan oppleve foreldrenes reduserte omsorgskapasitet ved at de har mindre overskudd og er mindre tilgjengelige for barna, at familien isolerer seg mer, eller at de gjør mindre ting sammen. Barn tar gjerne på seg voksenoppgaver og plikter, beskytter foreldrene ved å være mer hensynsfulle og be om mindre hjelp, eller ved ikke å snakke om egne tanker, følelser og bekymringer $(18,20)$.

\section{三 «Mange barn synes det er vanskelig å uttrykke tanker og følelser uten hjelp.»}

Mange barn synes det er vanskelig å uttrykke tanker og følelser uten hjelp, og kan føle seg utestengt, ensomme og alene. Barn forteller ofte om konsentrasjons- og læringsvansker på skolen, og problemer med å takle hverdagens utfordringer $(18,19)$. Barn har behov for struktur, klare rammer og forutsigbarhet i hverdagen for å oppleve trygghet. De etterlyser dermed en balansegang mellom det å få snakke om hvordan de har det og et frirom fra sykdom der de kan snakke om andre ting, være med venner, og delta på fritidsaktiviteter (18).

\section{Viktig nettverksstøtte}


Sosial støtte defineres som emosjonell, økonomisk og praktisk hjelp eller informasjon som er gitt til individer/familier av andre familiemedlemmer, venner, kollegaer og så videre (21). Sosial støtte er essensielt for menneskers fysiske og psykisk helse og livskvalitet, spesielt i kjølvannet av alvorlige livshendelser og kriser $(1,22)$. Årsakssammenhengen mellom nettverksstøtte og helse er uklar, men to hovedmodeller anvendes: «Direkte-modellen» oppfatter sosial støtte som en direkte positiv effekt på livskvalitet, mens «buffer-modellen» oppfatter sosial støtte som en beskyttelse mot stress (21). Selv om forklaringene rundt effekten av sosial støtte er kompleks, kan styrking av sosiale nettverk være essensielt for menneskets helse.

\section{Familiens støttenettverk}

Alle mennesker og familier inngår i en sosial sammenheng, der det enkelte familiemedlem er deltaker i flere ulike sosiale nettverk som vist nedenfor.

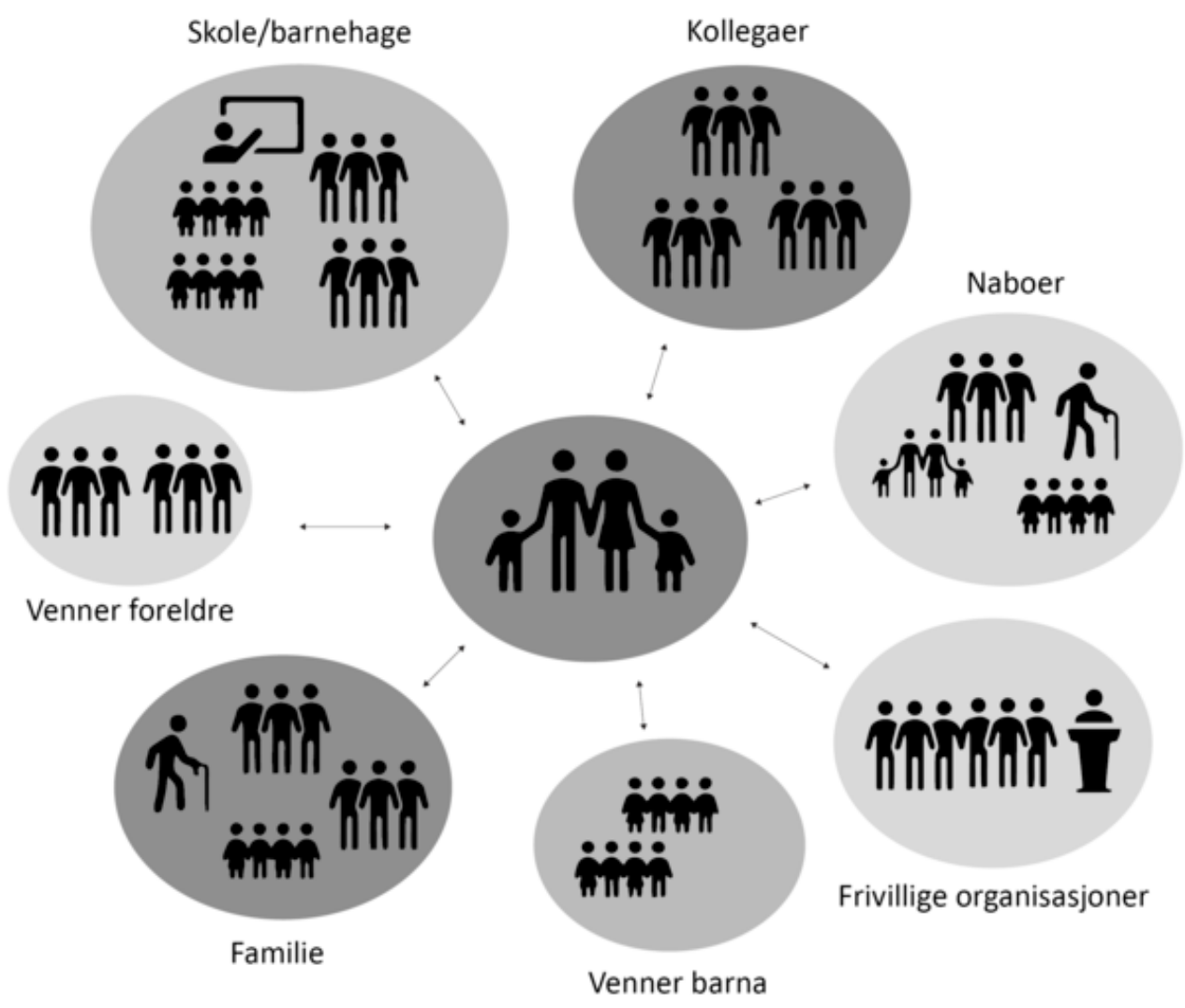


De som oftest står nærmest det enkelte familiemedlem består av personer vedkommende kjenner gjennom lang tid og som stadig er tilgjengelige for kontakt. Dette kan være familie, venner, skole, barnehage, arbeidskollegaer, naboer og frivillige organisasjoner som idrettslag og kirke. Nettverket rundt den enkelte familie kan derfor variere betydelig etter hvilke primærgrupper det enkelte familiemedlem deltar i. I en krisesituasjon er det spesielt viktig å ha et familieperspektiv og kartlegge familiens totale nettverk, da disse til sammen kan utgjøre en stor ressurs for familien.

Siden hvert familiemedlem er med i ulike primærgrupper i sitt dagligliv, vil forholdet mellom disse gruppene også ha betydning for den enkelte og familien totalt. For familier i krise, vil for eksempel samarbeidet mellom hjem-skole og hjem-venner, være spesielt viktig for å støtte familiens funksjon og livskvalitet.

\section{Samspill}

Siden de fleste familier er involvert i flere primærgrupper, kan familiens nettverk være ganske stort. Størrelsen på nettverket er ikke viktigst, men hvordan familien opplever at disse er til stede og møter deres behov. Forskning viser at nettverkene rundt familier i krise gjerne vil støtte og hjelpe, men at de ofte er usikre på hvordan de kan hjelpe. De rapporterer at de er redde for å si eller gjøre «gale» ting, at familien har mange andre rundt seg, eller at familien synes å klare seg godt selv. Mange trekker seg dermed unna fordi de ikke vil trenge seg på $(3,4)$.

\section{三 «De som støtter, opplever at det er givende og meningsfullt.»}


Forskning viser også at nettverksmedlemmer som støtter kriserammete opplever at det er givende og meningsfullt, at de utvikler seg selv og at vennskapsbånd kan bli tettere (4). Nettverket kan imidlertid oppleve at det kan være slitsomt, utfordrende og vanskelig å være en støtteperson, spesielt over tid, og de etterlyser mer kunnskap og opplæring om hvordan de best kan støtte. Sykepleiere kan derfor tilrettelegge for en bedre og mer langvarig nettverksstøtte gjennom å anerkjenne nettverkets viktige innsats og gi dem ulike strategier for hvordan støtte og hjelp best kan gis.

\section{God nettverksst $ø$ tte}

Både klinisk erfaring og forskning viser at det spesielt er noen former for nettverksstøtte som kriserammete verdsetter høyt $(3,4,10,23)$ :

1. Følelsesmessige/emosjonell støtte. Dette kan innebære å være en samtalepartner for den friske eller syke forelderen, eller barna. Ta seg tid og lytte, gi oppmuntring ut fra den situasjonen vedkommende er $\mathrm{i}$. Emosjonell støtte kan også innebære små oppmerksomheter som en hyggelig melding, et kort, en liten blomst, et bakverk eller liknende.

2. Praktisk støtte. De fleste familier setter stor pris på å få avlastning på en rekke praktiske områder. Eksempler på praktisk avlastning kan for eksempel være: kjøring til aktiviteter, husarbeid, hagearbeid, oppussing, barnepass, lekselesing, gjøre aktiviteter som barna liker, lage middag, bake, handle, følge til behandlinger og så videre. Mange familier synes imidlertid det er vanskelig å være konkret og er redde for å belaste nettverket. Her er det viktig med åpen kommunikasjon og at nettverket er på tilbudssiden.

3. Stimulering til «friminutt»/sosial støtte. Det er viktig for kriserammete å få pusterom fra det vanskelige, og gjøre ting som man tidligere hadde glede av. Her kan nettverket spille en sentral rolle for å stimulere til, for eksempel, sosiale og fysiske aktiviteter som gjør godt for kropp og sjel. Slik kan opplevelser man egentlig ikke ønsket å være med på, gi atspredelse og distraksjon som igjen gir overskudd og mestringsfølelse i hverdagen. 
4. Informasjon. De fleste familier i krise, er i en situasjon de har lite kunnskap om. Derfor kan informasjon på ulike områder være en stor støtte og til hjelp. Nettverket kan for eksempel hjelpe med å innhente informasjon om sosiale rettigheter og offentlig støtte, hjelpetilbud i kommunen, informasjon fra pasientorganisasjoner, formidle kontakt til likemenn og så videre. Her må imidlertid nettverket trå varsomt og avklare med familien om hvilken informasjon de ønsker og ikke gå bak ryggen deres.

5. Økonomisk støtte. Mange småbarnsfamilier har i utgangspunktet en stram økonomi og sykdom hos en forelder kan forverre situasjonen. Å be om økonomisk hjelp er gjerne noe de fleste foreldre finner aller vanskeligst å be om. Her er det viktig at støttepersoner er på tilbudssiden og er forsiktig i sin tilnærming. Slik hjelp kan også innebære å finne fram til rettigheter, gjøre avtaler med bank, eller organisere barnevakt slik at en frisk forelder klarer sine jobbforpliktelser.

\section{«Kjøreregler»}

Selv om behovene hos det enkelte familiemedlemmet vil være individuelle og mangeartete, og variere med sykdoms- og behandlingsutvikling, kan man peke ut noen sentrale prinsipper for god nettverksstøtte (2, 4, 18, 19, 23). Voksne vil oftest ha behov for å bli sett og forstått i sin unike situasjon, og få støtte uten at de føler at de belaster andre. De vil ha ulike praktiske behov tilpasset den livs- og sykdomsfasen familien befinner seg i. Barnas behov for støtte vil variere etter deres alder og forelderens sykdomsfase. Barna trenger spesielt normale livsopplevelser og sykdomsfrie soner, noe som ofte vil være hovedoppgaven for nettverksstøtten. Sykepleier kan med fordel informere nettverket om følgende sentrale prinsipper for god nettverksstøtte:

- Gi støtte på familiens premisser. Fordi behov for nettverksstøtte vil variere fra familie til familie, fra situasjon til situasjon, og også over tid, må nettverket tilpasses disse faktorene. Støtten må tilpasses det enkelte familiemedlem i forhold til kjønnsforskjeller og personlige ulikheter, og hvor komfortabel den enkelte er med å be om og motta hjelp, samt type 
hjelp. Nettverket må støtte på en slik måte at familien opplever å bli sett og støttet ut fra sin særegne situasjon. Støttepersoner må signalisere at de respekterer familiens autonomi, at de anerkjenner og respekterer deres situasjon og de valg de gjør, selv om en selv kan mene at andre valg ville vært bedre. Det er også viktig at støttepersoner unngår å gi "gode» råd de rammete ikke har bruk for eller bagatelliserer familiens situasjon, ved for eksempel å si «Det går nok bra skal du se» eller «Du må tenke positivt». Nettverket skal heller ikke komme med forslag til ulike «mirakelkurer» eller alternative behandlingsmetoder som familien ikke har bedt om, da dette oftest oppleves mer som en belastning enn støtte.

- Vær konkret og på tilbudssiden. Det er viktig at nettverket tar aktivt kontakt, er på tilbudssiden, og gjentar spørsmål om hvilken hjelp familien trenger over tid. Siden mange familier synes det er vanskelig å be om den hjelpen de faktisk trenger, opplever de ofte ikke «bare ring hvis jeg kan hjelpe» som et reelt tilbud om hjelp. Det viktigste er at man våger å ta kontakt, siden unnvikelse kan oppleves svært vanskelig og sårende for familien. Det er lettere å ta imot konkret hjelp enn generelle tilbud om hjelp. Støttepersoner oppmuntres derfor til å komme med konkrete tilbud for eksempel knyttet til barna, husarbeid, matlaging, handling, hagearbeid og slikt alt etter hva den enkelte har mulighet til. En syk mor fortalte om en venninne som ringte og spurte om skulle vaske badet hennes. Moren hadde aldri turt å spørre om slik hjelp, men syntes dette var fantastisk. Dette vil hun aldri ville glemme.

- Vis respekt for reaksjoner. Familiemedlemmene kan ha forskjellige reaksjoner på sin situasjon. Noen kan være sterke og synlige, mens andre holder det mer for seg selv. Støttepersoner kan finne det vanskelig å forstå slike ulike reaksjonsmønstre, og være fristet til å tenke at «jeg ville ikke reagert slik og sånn ...» - og også komme med råd. Det enkelte familiemedlem har behov for å bli sett og hørt som det unike individet de er, og det er derfor viktig at nettverket respekterer familiens reaksjoner, selv om de ikke «forstår» dem.

- Hjelp foreldre til å hjelpe barna. Et hovedprinsipp for hjelp til barn som lever $\mathrm{i}$ en kriserammet familie er at 
den beste hjelpen går gjennom foreldrene. Ved å st $\varnothing$ tte foreldrene kan deres omsorgskapasitet $\varnothing$ kes. God nettverksstøtte må derfor ha et familieperspektiv og tilpasses familiens behov. Slik hjelp kan derfor innebære direkte hjelp til foreldrene for å avlaste dem med praktiske oppgaver, slik at de får mer energi og kapasitet til å ta seg av barna. Man kan også hjelpe barna direkte med, for eksempel, leksehjelp eller ved å gi dem gode opplevelser gjennom en hyttetur og fisketur.

- Tilstreb åpen og tydelig kommunikasjon og praktiser «taushetsplikt». Siden nettverksstøtte skjer i samhandling mellom nettverket og familien er det viktig at familien er åpen og konkret når de beskriver sine behov for støtte. Tilsvarende er det viktig at nettverksmedlemmer er tydelige på hvilken hjelp de kan tilby, og legge listen slik at støtten kan opprettholdes over tid. En slik åpenhet gir økt trygghet hos begge parter og sørger for at støtten som gis er det en har behov for. Støtten må derfor balanseres mellom familiens behov og nettverkets muligheter. Familien må selv kunne velge (bort), avgrense og dosere hjelpen ut fra egne ønsker og behov, og nettverket må ikke love mer enn de kan holde.

For å bygge opp under familiens autonomi, inngi trygghet og vise respekt, er det viktig at familiemedlemmene kan være trygge på at de ikke blir «snakket om». Dette kan nettverket forsikre om ved å avklare hva de kan si utad om familiens situasjon, og ellers overholde taushetsplikt om andre ting de får kjennskap til.

- Fordel hjelpen i nettverket og gi støtte over tid. Ut fra prinsippet om at ikke alle kan gjøre alt, er det viktig at nettverket samarbeider og at støtten koordineres. Ettersom mange familier lever $i$ en vedvarende krisesituasjon over lengre tid, er det vesentlig at støtten opprettholdes over tid. Fordeler man oppgavene blir hjelpen overkommelig, både for den som gir og for vedkommende som tar imot, og den er lettere å opprettholde over tid. Det kan være lurt å bytte eller rullere på oppgaver, ha planlagte pauser innimellom, og kople på flere nettverksmedlemmer dersom det er relevant. Koordineringen kan gjøres på ulike måter, for eksempel gjennom en lukket facebookgruppe der familien legger ut sine behov, 
eller at familien på andre måter får uttrykt sine behov for støtte. Koordinering av støtten kan imidlertid oppleves som en tilleggsbelastning for familien, og noen familier oppretter derfor en støttekoordinator, for eksempel en venn, et familiemedlem, en nabo eller liknende.

- Stol på at din hjelp er viktig og uttrykk at det er godt å være en støttespiller. Det er viktig at nettverket innser at ulike mennesker kan gi ulike former for støtte, og at ingen støtte er «mer verdifull» enn en annen. Dette innebærer aksept for at familien finner det naturlig at de snakker med noen, får praktisk hjelp av andre, får hjelp til barnepass av andre og slikt. En tydelig oppgavefordeling gjør det dessuten lettere å ta imot hjelp og oppleve at man ikke overbelaster nettverket. Oppgavefordeling innad i nettverket kan også bidra til at nettverksstøtte kan vare over tid.

For å unngå at sosial nettverksstøtte blir til en givermottaker situasjon, der familien kommer i en takknemlighetsposisjon er det viktig at nettverket uttrykker hva de opplever i situasjonen. Selv om hva som «gis» og hva som «mottas», kan være ulikt, opplever mange nettverksmedlemmer som støtter kriserammete at det er viktig og verdifullt for dem å være til stede. Familien må derfor fortelles at det kan være en ære å bli invitert inn som en viktig støttespiller i en vanskelig livssituasjon.

\section{Oppsummering}

Alvorlig sykdom hos en forelder påvirker hele familien, der foreldrenes omsorgskapasitet ofte reduseres og barnas omsorgsbehov ikke møtes. Til tross for betydningen av sosial støtte og at nettverk ofte ønsker å støtte, viser forskning at det kan være en utfordring å få utnyttet alle potensialene som ligger i et nettverk. Ved å oppmuntre familier i krisesituasjoner til å involvere sine sosiale nettverk, kan familienes totale situasjon forbedres i en vanskelig livssituasjon. Sykepleiere har en viktig oppgave i å optimalisere sosial nettverksstøtte til kriserammete familier, gjennom informasjon og undervisning om ulike typer støtte som kriserammete verdsetter og prinsipper for god nettverksstøtte. 


\section{Referanser}

1. Albrecht TL, Goldsmith DJ. Social support, social networks, and health. Mahwa.: Erlbaum; 2003.

2. Dyregrov K. Når foreldre har alvorlig kreftsykdomeller dør av den. I: Haugland BS, Ytterhus B, Dyregrov K. Barn som pårørende. Oslo: Abstrakt Publisher; 2012.

3. Dyregrov K. Experiences of social networks supporting traumatically bereaved. Omega-J Death Dying. 2005;52(4): 339-58.

4. Dyregrov K, Dyregrov A. Barn og unge som pårørende ved kreft. Hvordan kan barns situasjon og foreldres omsorgskapasitet styrkes i et rehabiliteringsperspektiv? Bergen: Senter for krisepsykologi, 2011.

5. Krauel K, Simon A, Krause-Hebecker N, Czimbalmos A, Bottomley A, Flechtner H. When a parent has cancer: challenges to patients, their families and health providers. Expert Rev Pharm Out. 2012;12(6): 795-808.

6. Kim Y, Given BA. Quality of life of family caregivers of cancer survivors - Across the trajectory of the illness. Cancer. 2008;112 (11): 2556-68.

7. Dyregrov A, Dyregrov K, Heltne U, Bø B, Eriksen K. Hva menes med kriser og katastrofer Bergen: Senter for krisepsykologi; 2009 Tilgjengelig fra: http://www.kriser.no/organisering/begrep/ (nedlastet 06.11.2017).

8. Goldbeck L, Ruffer JU. Late effects of cancer. Nervenheilkunde. 2011;30(3): 164-8.

9. Jim HSL, Jacobsen PB. Posttraumatic Stress and Posttraumatic Growth in Cancer Survivorship: A Review. Cancer J. 2008;14(6): 414-9. 
10. Senneseth M, Hauken MA, Matthiesen SB, Gjestad R, Laberg JC. Facing Spousal Cancer during Child-Rearing Years: Do Social Support and Hardiness Moderate the Impact of Psychological Distress on Quality of Life? Cancer Nurs. 2016.

11. Visser A, Huizinga GA, van der Graaf WT, Hoekstra HJ, Hoekstra-Weebers JE. The impact of parental cancer on children and the family: a review of the literature. Cancer Treat Rev. 2004;30(8): 683-94.

12. Turner D, Adams E, Boulton M, Harrison S, Khan N, Rose P, et al. Partners and close family members of long-term cancer survivors: health status, psychosocial well-being and unmet supportive care needs. PsychoOncology. 2013;22(1): 12-9.

13. Phillips F. Adolescents living with a parent with advanced cancer: a review of the literature. PsychoOncology. 2014;23 (12): 1223-39.

14. Adams E, Boulton M, Watson E. The information needs of partners and family members of cancer patients: A systematic literature review. Patient Education and Counseling. 2009;77(2): 179-86.

15. Krattenmacher T, Kuhne F, Ernst J, Bergelt C, Romer G, Moller B. Parental cancer: Factors associated with children's psychosocial adjustment - a systematic review. Journal of Psychosomatic Research. 2012;72(5): 344-56.

16. Grabiak BR, Bender CM, Puskar KR. The impact of parental cancer on the adolescent: An analysis of the literature. Psycho-Oncology. 2007;16(2): 127-37.

17. Hauken MA, Pereira M, Senneseth M. The effects on children's anxiety and quality of life of a psychoeducational program for families living with parental cancer and their network - an RCT study. Cancer Nurs. 2017. 
18. Morgen M. Omsorgsmålingen. Når sorgen rammer. En undersøgelse af trivsel og støtte, når børn og unge oplever dødsfald eller sygdom i familien. Mandag Morgen Innovation ApS \& Egmont Fonden, 2013.

19. Hauken MA, Senneseth M, Dyregrov A, Dyregrov K. Anxiety and the Quality of Life of Children Living with Parental Cancer. Cancer Nurs. 2017.

20. Osborn T. The psychosocial impact of parental cancer on children and adolescents: a systematic review. Psycho-Oncology. 2007;16(2): 101-26.

21. Cohen S, Underwood LG, Gottlieb BH. Social support measurement and intervention. A guide for health and social scientists. New York: Oxford University Press; 2000.

22. Decker CL. Social support and adolescent cancer survivors: A review of the literature. Psycho-oncology. 2007;16(1): 1-11.

23. Senneseth M, Dyregrov A, Laberg J, Matthiesen SB, Pereira M, Hauken MA. «Facing spousal cancer during child-rearing years: the short-term effects of the Cancer-PEPSONE program - a single-center randomized controlled trial». Psycho-Oncology. 2016. 